Kapata Arkeologi, 13(2), 163-178

ISSN (cetak): 1858-4101

ISSN (elektronik): 2503-0876

http://kapata-arkeologi.kemdikbud.go.id

\title{
FESTIVAL MENONGKAH: REVITALISASI BUDAYA DAN BAHASA DUANU MENUJU INDUSTRI KREATIF
}

\section{Menongkah Festival: Revitalization of Duanu Culture and Language toward Creative Industry}

\author{
Dessy Wahyuni \\ Balai Bahasa Riau - Indonesia \\ Jl. Binawidya, Kompleks Universitas Riau, Panam, Pekanbaru 28292 \\ dessy_wahyuni@yahoo.com \\ Naskah diterima: 22/07/2017; direvisi: 03/10 - 06/11/2017; disetujui: 17/11/2017 \\ Publikasi elektronik: 30/11/2017
}

\begin{abstract}
The life of the Malay Duanu community, a remote indigenous community, is started to be exposed recently. Their existence is recognized by the world through the Menongkah Festival that has achieved the MURI record twice. Unfortanely, following the current globalization progress, the expose of this ethnic group starts to erodes their culture and language toward extinction. It is unfortunate as wel that this activity only highlight the ceremonial part. In fact, Duanu people can take advantage of this Menongkah Festival as a medium for the revitalization of Duanu language and culture. If the festival is managed well, then it is believed that this activity will be able to support the emergence of a creative economy that improves the welfare of its supporting community, as well as to revitalize their culture and language. The government should be able to create policies that capable to support the creation of locality-based creative mindset, systems, and practices of the creative industry and to keep prioritizing the existing cultural values. Therefore, through ethnographic methods, the aim of this paper is to offer the model of creative industries based on culture and language of Duanu. If Menongkah Festival is optimally utilized by developing creative undustries, it is believed that the endangered language and culture of Duanu cen be revitalized and people's live will be more prosperous.
\end{abstract}

Keywords: Menongkah Festival, Duanu, revitalization, Duanu language, creative industry

\section{Abstrak}

Kehidupan masyarakat Melayu Duanu, sebuah komunitas adat terpencil saat ini mulai mengemuka. Eksistensi mereka diakui dunia melalui Festival Menongkah yang mendapatkan rekor MURI sebanyak dua kali. Namun tanpa disadari, seiring arus globalisasi yang menerpa, mengemukanya suku ini mengikis budaya dan bahasa Duanu secara perlahan ke arah kepunahan. Selain itu sangat disayangkan, kegiatan ini hanya menyorot kemeriahan sesaat. Padahal masyarakat Duanu bisa memanfaatkan Festival Menongkah ini sebagai media revitalisasi budaya dan bahasa Duanu. Apabila dikelola dengan baik, diyakini, kegiatan ini akan dapat menjadi penopang munculnya ekonomi kreatif yang meningkatkan kesejahteraan masyarakat pendukungnya, sekaligus dapat merevitalisasi budaya dan bahasa mereka. Pemerintah seharusnya dapat membuat kebijakan yang mampu mendukung terciptanya pola pikir, sistem, dan praktik industri kreatif berbasis lokalitas dan tetap mengedepankan nilai-nilai kultural yang ada. Dengan demikian, melalui metode etnografis, tulisan ini bertujuan menawarkan model industri kreatif berbasis budaya dan bahasa Duanu. Jika Festival Menongkah dimanfaatkan secara maksimal dengan mengembangkan industri kreatif, diyakini bahasa dan budaya Duanu yang nyaris punah dapat terevitalisasi serta kehidupan masyarakat pun semakin makmur.

Kata kunci: Festival Menongkah, Duanu, revitalisasi, Bahasa Duanu, industri kreatif

\section{PENDAHULUAN}

Indonesia merupakan negara dengan keanekaragaman suku bangsa yang terbilang besar di dunia. Salah satu suku tersebut adalah suku Laut. Suku ini berada di wilayah Riau dan Kepulauan Riau. Suku Laut ini hidup di atas rumah perahu, berkelana dari satu tempat ke tempat yang lain di permukaan laut. Suku ini memiliki kekayaan alam, budaya, dan manusia. Kekayaan alam, budaya, dan manusia dapat menghasilkan potensi besar ketika digabung dengan kreativitas sehingga dapat memberikan sumbangsih pada berbagai sektor. Tidak hanya sokongan terhadap perekonomian nasional, potensi yang dihasilkan tersebut juga dapat menguatkan citra dan identitas bangsa. Ekonomi 
kreatif memiliki potensi besar untuk menjadi salah satu sektor penggerak yang dapat menangkap peluang ini. Ekonomi kreatif tidak hanya mengenai penciptaan nilai tambah secara ekonomi, tetapi juga penciptaan nilai tambah secara sosial, budaya, dan lingkungan. Industri kreatif yang merupakan subsistem dari ekonomi kreatif menjadi penggerak dalam menciptakan nilai-nilai tersebut. Penggalian kebudayaan ini penting dilakukan dengan meningkatkan kreativitas agar dapat memicu daya saing daerah (kelokalan). Penggalian kebudayaan menuju industri kreatif ini telah dibahas dalam beberapa kajian, seperti yang ditulis oleh Saksono (2012: 93-94), Nyoman \& Wayan (2014: 71-72), AlMa'ruf (2015: 12-14), Suardina (2011: 204), Anoegrajekti, Setyawan, Saputra, \& Macaryus (2015: 83), dan Mahyarni, Meflinda, Bustam, \& Tanjung (2015: 620-621). Kebermanfaatan industri kreatif ini perlu untuk dipromosikan di berbagai media agar terus mendapatkan kontribusi dari banyak pihak (Susanti \& Ichsani, 2012: 441).

Hal ini penting dicermati karena masyarakat Duanu sebenarnya memiliki kekayaan alam, budaya, dan manusia. Sumber daya alam yang ada di laut menjadi sumber kehidupan masyarakat Duanu. Akan tetapi, berbagai sarana dan prasarana yang berkembang di era globalisasi ini mengganggu harmonisasi alam dan lingkungan yang ada (Abidin, 2014: 40). Sebagai komunitas adat terpencil di Provinsi Riau, Masyarakat Duanu merasa minder dengan bahasa dan kebudayaan yang mereka miliki. Dalam pergaulan sehari-hari, mereka cenderung meninggalkan bahasa dan kebudayaan mereka tersebut. Suku Duanu memiliki ketergantungan yang sangat tinggi terhadap laut. Dahulu, mereka hidup berpindahpindah antarpulau dan mengembara di lautan. Laut adalah lahan mereka, tempat menggantungkan harapan dan sumber kehidupan. Bermukim dalam sampan yang selalu berpindahpindah tempat memang sesuai dengan kebiasaan mereka mencari dan memburu ikan di laut. Mereka mencari dan memburu ikan pada perubahan musim dari setiap pergeseran angin dan arus laut yang selalu mempengaruhi daerah perburuan mereka.

Saat ini, masyarakat Duanu telah mengalami peningkatan peradaban. Masyarakat awam telah mulai mengenyahkan pemikiran tentang kemarginalan suku Duanu. Masyarakat Duanu perlahan telah bisa meningkatkan perekonomian keluarga, berhasil mengikuti arus modernisasi, serta mampu bersaing dengan komunitas lain di peradaban modern ini. Namun, tanpa disadari, mereka juga telah mengikis bahasa dan budaya secara perlahan hingga menuju kepunahan di muka bumi ini (Wahyuni, 2013: 2). Seperti halnya seleksi alam yang menimpa makhluk hidup sejalan dengan teori evolusi yang dikemukakan oleh Charles Darwin kini terjadi pula pada bahasa. Sejumlah bahasa di dunia terancam punah. Kekhawatiran ini sudah menyeruak dengan mulai berkurangnya, bahkan hilang, penutur bahasa daerah tersebut. Peristiwa ini menggelisahkan Sarpan Firmansyah. Tokoh inspiratif yang mendapat "Liputan6 Awards SCTV" tahun 2013 ini selalu berupaya agar puaknya tidak lenyap oleh peradaban. Untuk itu, ia pun menggagas sebuah festival budaya yang bisa memperkenalkan sukunya ke hadapan publik, yakni Festival Menongkah.

Festival Menongkah, sebagai sebuah ajang kebudayaan, menampilkan berbagai kebudayaan masyarakat Duanu. Dalam festival tersebut, tidak hanya lomba menongkah yang ada, tetapi juga seminar tentang eksistensi menongkah, lomba buka kerang sebelah tangan, lomba menganyam tengkalang, lomba merajut belat, lomba berdenden, serta lomba permainan rakyat Duanu, seperti permainan seremban kulit kerang dan permainan congkak kulit kerang. Pemerintah menyambut baik kegiatan ini dan telah mengagendakan kegiatan ini sebagai program rutin tahunan. Festival Menongkah Heritage ini, menurut Junaidi (Kepala Disporabudpar Indragiri Hilir), memperkenalkan kepada dunia luar bahwa etnis Duanu juga memiliki kebudayaan yang menunjukkan bahwa mereka memiliki semangat juang yang tinggi dan memperkaya khazanah budaya di Indragiri Hilir (Advetorial, 2016). Namun sangat disayangkan, kegiatan ini hanya bersifat perayaan sementara. Bahkan, tanpa disadari, bahasa dan budaya Melayu Duanu yang semestinya berfungsi sebagai jati diri puak Duanu, pun ikut tergerus modernisasi. Padahal, apabila dikelola dengan baik, Festival Menongkah ini diyakini dapat menjadi penopang munculnya ekonomi kreatif yang meningkatkan kesejahteraan masyarakat pendukungnya, sekaligus dapat merevitalisasi budaya dan bahasa mereka.

Jika dikombinasikan dengan kreativitas, peluang ekonomi kreatif akan muncul dan melahirkan wujud kreativitas baru dalam industri kreatif. Industri kreatif ini tidak hanya menghasilkan berbagai produk dari seni budaya, 
tetapi juga dapat menghasilkan produk yang penting dalam kehidupan sehari-hari, serta dapat merevitalisasi budaya dan bahasa Duanu yang hampir punah itu. Suku Duanu saat ini berada pada posisi kritis. Bahasa dan budaya mereka telah tergerus oleh zaman. Hanya generasi tua saja kini yang bisa menuturkan bahasa ibu mereka dengan baik. Tradisi mereka pun mulai ditinggalkan. Generasi muda bahkan tidak memahami bahasa ibu mereka. Suku ini pun nyaris menjadi kenangan sejarah belaka.

Dalam "Pemertahanan Bahasa Melayu Riau" yang terangkum dalam Anomali Bahasa (Danardana, 2011: 57) dikatakan bahwa bahasa memiliki arti penting. Apalagi setelah diketahui bahwa setiap dua minggu dunia kehilangan satu bahasa. Separuh dari 5.000 bahasa di dunia saat ini akan lenyap dalam satu abad ke depan (Andrew Dalby dalam bukunya Language in Danger, 2003). Padahal bahasa mencerminkan cara pandang penuturnya terhadap dunia. Punahnya sebuah bahasa, dengan demikian berarti hilang pula khazanah ungkapan yang mencerminkan cara pandang penuturnya terhadap dunia. Ancaman hilangnya bahasa Duanu merupakan sebuah persoalan serius. Jika bahasa Duanu punah, akan punah juga suku tersebut. Dengan demikian, budayanya pun akan sirna. Hal ini merupakan sebuah kondisi yang mencemaskan. Mereka masih mengaku orang Duanu, tetapi sudah tidak bisa bertutur menggunakan bahasa asli mereka. Hal ini tentu saja akan mengakibatkan bahwa suatu saat suku Duanu tak bisa lagi diakui sebagai etnik yang spesifik, karena sudah tidak memiliki bahasa yang menunjukkan bangsa.

Festival Menongkah, pada awalnya dimaksudkan untuk menjawab kegelisahan ini. Akan tetapi, ekonomi kreatif sebagai suatu konsep untuk merealisasikan pembangunan ekonomi berkelanjutan berbasis kreativitas yang dituju belum tercapai secara maksimal. Ide, kreativitas, keahlian, dan bakat para pemangku kepentingan belum tergali dan belum termanfaatkan secara optimal dan menyeluruh dalam mengelola sumber daya yang ada. Penguatan identitas Duanu bukan pada proses euforia semata, melainkan juga pada identitas Duanu yang dikaitkan dengan penopang kemakmuran. Dengan mengusung ekonomi kreatif, menciptakan lapangan kerja baru, mengurangi pengangguran, menyemarakkan dunia pariwisata, dan sebagainya, kehidupan rakyat menjadi lebih baik tanpa meninggalkan bahasa daerah pengusung jati diri kesukuan.
Ekonomi kreatif tidak hanya mengenai penciptaan nilai tambah secara ekonomi, tetapi juga penciptaan nilai tambah secara sosial, budaya, dan lingkungan. Industri kreatif yang merupakan subsistem dari ekonomi kreatif menjadi penggerak dalam menciptakan nilai-nilai tersebut.

Dengan demikian, tulisan ini bertujuan untuk menjelaskan bagaimana industri kreatif berbasis budaya lokal dan bahasa Duanu ini dapat dikembangkan. Dengan metode etnografis dan analisis kultural, model tersebut diharapkan mampu membuka jalan dalam mengembangkan industri kreatif di wilayah lokal.

\section{METODE}

Sebagai sebuah persoalan kebudayaan dan kebahasaan, Festival Menongkah dikaji secara etnografis untuk memperlihatkan revitalisasi kebudayaan dan kebahasaan tersebut menuju industri kreatif dengan memusatkan perhatian pada sistem pengetahuan yang dimiliki subjek dan bagaimana pengetahuan itu diorganisasikan untuk menentukan tindakan. Selain itu, metode etnografi digunakan untuk menemukan bagaimana masyarakat mengorganisasikan budaya dalam pikiran mereka dan kemudian menggunakan budaya tersebut dalam kehidupannya.

Kajian etnografi ini merupakan kegiatan pengumpulan bahan keterangan atau data yang dilakukan secara sistematik mengenai cara hidup serta berbagai aktivitas sosial dan berbagai benda kebudayaan dari sumber masyarakat. Etnografi pada dasarnya lebih memanfaatkan teknik pengumpulan data pengamatan berperan serta (participant observation). Pendekatan ini merupakan ragam pemaparan penelitian budaya untuk memahami cara orang-orang berinteraksi dan bekerja sama melalui fenomena teramati dalam kehidupan sehari-hari (Endraswara, 2012: 50-51).

Melalui etnografi, kajian ini bertujuan untuk menguraikan budaya Duanu secara holistik, yaitu aspek budaya baik spiritual maupun material. Dari sini akan terungkap pandangan hidup dari sudut pandang masyarakat Duanu tersebut. Melalui pendekatan ini terlihat keberadaan fenomena budaya masyarakat senyatanya. Pengumpulan data dalam penelitian ini juga menggunakan metode studi pustaka dengan teknik catat. Peneliti sebagai instrumen utama dalam kajian ini mencatat hal atau temuan data yang dijadikan model analisis data. Sementara itu, kartu data digunakan sebagai 
pencatat data yang merupakan instrumen pelengkap.

\section{HASIL DAN PEMBAHASAN}

\section{Suku Duanu}

Orang Laut atau Orang Kuala di Provinsi Riau dikenal dengan nama suku Duanu. Istilah Duanu ini, menurut Sarpan Firmansyah, merupakan bahasa Belanda duane 'upeti,' 'pajak,' atau 'cukai.' Pada masa kerajaan Riau-Lingga, suku bangsa ini kerap diperintah oleh Raja Lingga untuk memungut pajak kepada setiap kapal yang berlabuh. Lalu, kepada setiap kapten kapal yang datang, orang-orang di kuala tersebut selalu menyerukan, "Hei, duane!" agar mereka segera menyerahkan pajak atau upeti. Istilah ini akhirnya menjadi ejekan dan melekat terus bagi suku Laut (Danardana, Wahyuni, Sarmianti, \& Diandini, 2013: 26).

Namun, Sarpan juga memberikan gambaran lain tentang asal-usul kata duanu. Menurutnya, kata duanu berasal dari duak 'jauh' dan neh 'sangat.' Hal ini bermakna bahwa "duanu" berada sangat jauh dari peradaban manusia pada umumnya, sebab mereka berada dan beraktivitas di lautan. Selain itu, kebiasaan mereka yang hidup berkoloni di muara sungai ataupun di pesisir pantai, sangat jauh dari pandangan orang-orang di darat. Oleh sebab itulah mereka disebut duak neh (Danardana et al., 2013: 26).

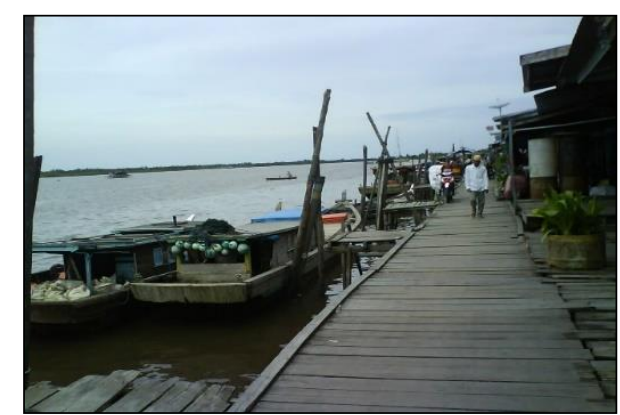

Gambar 1. Jerambah Kayu

(Sumber: https://simburnaikupdate.wordpress.com, 2014)

Komunitas dan cara hidup suku Laut di Riau dan Kepulauan Riau memiliki perbedaan, salah satunya adalah agama. Di Riau, semua suku bangsa ini beragama Islam, berbeda dengan orang suku Laut di daerah lain. Sejak zaman nenek moyang, mereka telah memeluk agama Islam. Hal ini pulalah yang mungkin menyebabkan mereka tidak suka disebut orang Laut. Mereka bangga disejajarkan dengan suku Melayu, yang menjadikan agama Islam sebagai satu-satunya agama yang sah dan resmi. Oleh karena itu, mereka cenderung menamai diri dengan istilah Duanu, bukan suku Laut. Meskipun mereka jauh dari peradaban (seperti asal-usul nama suku mereka), tetapi mereka pemeluk agama Islam sejati.

Sifat mobilitas geografis suku Duanu ini sangat tinggi, sebab mereka suka berpindahpindah tempat antarpulau dan mengembara di lautan. Ketergantungan mereka pada laut sangat tinggi. Laut adalah lahan mereka, tempat menggantungkan harapan dan sumber kehidupan. Bermukim dalam sampan yang selalu berpindahpindah tempat memang sesuai dengan kebiasaan mereka. Kebiasaan itu adalah mencari dan memburu ikan di laut pada perubahan musim dari setiap pergeseran angin dan arus laut yang selalu mempengaruhi daerah perburuan mereka.

Istilah Duanu yang melekat pada orang Laut di Riau saat ini mulai dipopulerkan dalam seminar Peningkatan SDM Suku Laut pada 14 Mei 1993 di Pekanbaru. Sejak itu istilah Duanu mulai disosialisasikan kepada seluruh orang Laut di Riau. Istilah ini akhirnya dikukuhkan pada pertemuan akbar masyarakat Duanu se-Riau yang diselenggarakan pada 9-10 Juli 2003. Nama Duanu kini lebih dikenal daripada istilah suku Kuala, suku Nelayan, atau suku Laut.

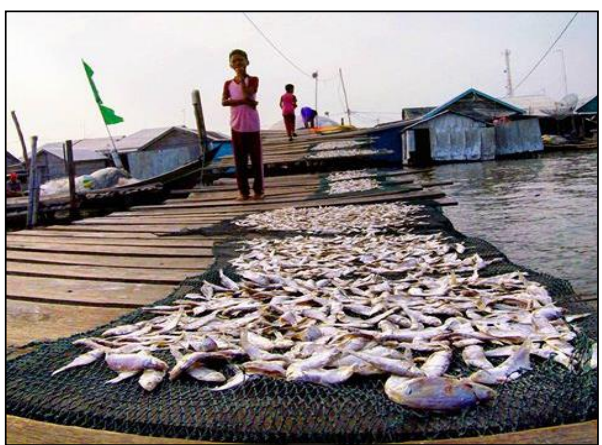

Gambar 2. Hasil Tangkapan Masyarakat Duanu (Sumber: http://www.imgrum.org/user/tripriau, 2016)

Keberadaan suku Duanu dipengaruhi oleh kebudayaan Melayu dan ajaran Islam yang menyebar lewat lautan dan perdagangan. Bahasa mereka juga dipengaruhi oleh bahasa Melayu, sebab wilayah pesisir yang mereka diami bersinggungan langsung dengan wilayah Melayu. Bahkan kini warga Duanu lebih fasih menggunakan bahasa Melayu daripada bahasa Indonesia. Hidup yang berpindah-pindah menjadi satu penyebab tidak lancarnya mereka berbahasa Indonesia. 
Pada 1980-an, pemerintah Orde baru mulai mengajarkan mereka untuk berumah di darat melalui program bantuan rumah layak huni. Salah satu penyebab mereka dimukimkan adalah penegasan batas-batas (demarkasi) yang memisahkan satu wilayah dengan wilayah lainnya, seiring dengan terbentuknya negaranegara pascakolonial di kawasan Asia Tenggara termasuk Republik Indonesia. Dalam konteks wilayah kultural suku Duanu yang sebagian besar adalah laut, hampir tidak ada lagi tempat bagi suku ini berpijak dan mencari kebutuhan pokok mereka secara bebas. Kondisi inilah yang menyebabkan mereka terpaksa menetap di beberapa tempat dan tidak lagi bisa hidup berpindah sesuka hati. Pada 1990-an, suku Duanu sudah tidak ada lagi yang hidup berkelompok di rumah sampan (perahu) beratap kajang (anyaman tradisional terbuat dari daun mengkuang, sejenis pandan berduri yang bayak tumbuh di pinggir sungai untuk menutup sampan). Mereka menetap di sekitar pesisir pantai dan muara sungai, karena mereka masih tetap setia dengan mata pencaharian utama mereka, yaitu nelayan. Jadi, mereka tetap tidak bisa dipisahkan dari kehidupan laut. Ketika perkampungan mereka dimasuki oleh suku-suku lain, sebagian mencari permukiman baru. Sementara itu, ada yang tetap tinggal dan hidup berbaur dengan suku-suku tersebut, seperti Melayu, Bugis, Banjar, Jawa, Minang, Cina, dan lain-lain. Mereka mulai membuka diri dari belenggu ketertutupan dan bergaul dengan warga lain. Meski masih tetap bergantung hidup mencari rezeki pada laut, tetapi mereka sudah mulai beradaptasi pada kehidupan yang lebih beradab.

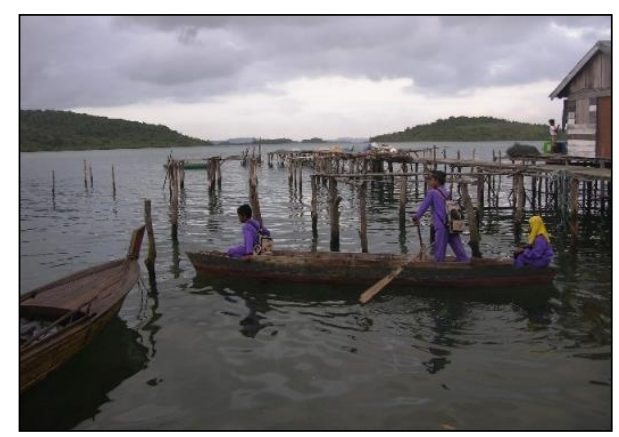

Gambar 3. Permukiman Suku Duanu

(Sumber: https://ariesaja.wordpress.com, 2015)

Secara umum, rumah-rumah Suku Duanu merupakan rumah panggung yang terbuat dari kayu dan berderet rapi bersama rumah-rumah lainnya. Awal pembuatan rumah adalah dengan memancangkan tiang, yang kemudian diberi rusuk (penghubung antartiang). Kemudian, untuk dasar lantai dipasang gelegar, yaitu kayu (balok) penyangga papan lantai (pada rumah panggung). Setelah lantai memiliki dasar, dipasang bendul (dasar dinding); bendul nebah (bawah), bendul nedis (atas), dan jenang (rangka untuk menempelkan dinding). Setelah itu, barulah dipasang kudu-kudu (kuda-kuda) dan kasu atup (kasau-kasau). Permukiman mereka ini tidak memiliki halaman, tetapi hanyalah jerambah papan yang sambung-menyambung. Jerambah ini pun kemudian disambung ke pelantar yang akan menjadi jalan utama perkampungan. Bagian bawah rumah atau pun pelantar hanyalah daratan berlumpur yang terhampar. Hamparan itu akan segera berubah menjadi lautan saat pasang naik.

Meskipun sudah dirumahkan, suku Duanu masih tetap tidak meninggalkan laut. Mereka masih mengandalkan sampan dan alat penangkap ikan sederhana; jala, jaring, lukah, toguk (alat penangkap udang), sondong (alat penangkap udang yang menggunakan motor), belat (jaring panjang), pukat, pancing, dan sebagainya, untuk mencari nafkah. Selain itu, orang Duanu juga sangat ahli menongkah, yaitu aktivitas menangkap kerang dalam lumpur dengan menggunakan sebilah papan sebagai tumpuan. Saat ini, Duanu tersebar di tiga belas desa pada tujuh kecamatan, Kabupaten Indragiri Hilir, Riau. Mereka sudah tidak ada lagi yang berumah perahu. Mereka mendiami permukiman yang tetap tidak jauh dari laut, tetapi sudah berbaur dengan suku lainnya. Dalam percakapan sehari-hari, saat ini masyarakat Duanu cenderung menggunakan bahasa Melayu dan mulai melupakan bahasa ibu mereka, terutama orang-orang muda serta anak-anak. Tidak sedikit dari mereka yang sudah tidak mengenal bahasa Duanu. Secara umum, bahasa Duanu memiliki banyak kemiripan dengan bahasa Melayu. Hal ini disebabkan karena Duanu merupakan salah satu Melayu Tua (Proto Malay). Namun, bahasa orang Laut ini tetap berbeda dengan bahasa Melayu tersebut. Oleh sebab itu, seharusnya warga Duanu, khususnya kawula muda, bangga terhadap bahasa daerah mereka ini dan mampu mempertahankan eksistensi bahasa Duanu agar tidak lenyap dari muka bumi (Danardana et al., 2013).

Pengucapan bahasa Duanu bagian utara berbeda dengan bahasa Duanu bagian selatan. Duanu bagian utara meliputi dua kecamatan, yakni Kecamatan Mandah (Desa Belaras dan Desa Bekawan) dan Kecamatan Kateman (Desa Kuala Selat dan Kelurahan Bandar Sri Gemilang). 
Sementara, Duanu bagian selatan meliputi lima kecamatan, yakni Kecamatan Concong (Desa Concong Luar dan Desa Panglima Raja), Kecamatan Kuala Indragiri (Desa Sungai Belah dan Desa Perigi Raja), Kecamatan Tanah Merah (Desa Tanah Merah, Desa Tanjung Pasir, dan Desa Sungai Laut), Kecamatan Kuala Sungai Batang (Desa Kuala Patahparang), serta Kecamatan Reteh (Pulau Ruku). Sarpan Firmansyah, tokoh Duanu yang seorang sarjana perikanan, sangat mengkhawatirkan kondisi ini. Ketua Kerukunan Keluarga Besar Masyarakat Duanu Riau ini melakukan berbagai upaya sebagai bentuk revitalisasi yang diyakininya dapat menghidupkan kembali bahasa daerahnya. Salah satu upaya tersebut adalah menggelar Festival Menongkah.

\section{Menongkah}

Menongkah kerang adalah teknik orang Duanu dalam menangkap kerang di padang lumpur. Menongkah ini menggunakan sebilah papan yang digunakan sebagai tumpuan sebelah kaki penongkah dan tempat mengumpulkan kerang yang telah diperoleh. Sementara itu, kaki penongkah yang sebelah lagi digunakan sebagai pengayuh tongkah. Sebuah tongkah biasanya terbuat dari belahan kayu besar dalam keadaan utuh, tetapi tidak jarang juga tongkah terdiri atas gabungan beberapa belahan papan. Biasanya tongkah memiliki panjang sekitar 1,5 meter hingga 2,2 meter, lebar $50 \mathrm{~cm}$ hingga $80 \mathrm{~cm}$, serta ketebalan kayu sekitar $3 \mathrm{~cm}$ hingga $5 \mathrm{~cm}$. Dalam Kamus Besar Bahasa Indonesia (Departemen Pendidikan Nasional, 2008: 1205), kata tongkah merupakan papan untuk titian yang biasanya dipasang di tempat becek atau basah. Tongkah oleh orang Duanu merupakan alat bantu berupa papan seperti papan selancar, yang digunakan untuk mencari atau menangkap kerang atau tiangan di pantai berlumpur atau beting. Aktivitasnya disebut menongkah (mut tiangan atau $m u d s k i$ atau ski lumpur).

Tongkah umumnya terbuat dari jenis kayu pulai maupun jelutung, serta berbagai jenis kayu lainnya. Kayu pulai menjadi pilihan utama, sebab selain tahan terhadap kebocoran, kayu pulai memiliki daya apung yang sangat tinggi. Jika menggunakan kayu lain, papan tongkahnya harus ditambah agar lebih lebar. Dalam penyambungan itu biasanya terjadi kebocoran yang bisa mengganggu kinerja para penongkah. Kedua ujung tongkah berbentuk lonjong (lancip) dan melentik ke atas seperti papan selancar yang sering digunakan oleh olahragawan air (peselancar). Hal ini bertujuan agar pergerakan di atas lumpur menjadi lancar. Bila ujung papan kurang melentik, seringkali tongkah menghunjam atau menancap ke dalam lumpur. Pada bagian atas papan inilah satu kaki penggunanya ditopangkan. Sementara kaki yang satunya lagi digunakan untuk mendorong agar papan tongkah bisa bergerak cepat di atas pantai yang berlumpur.

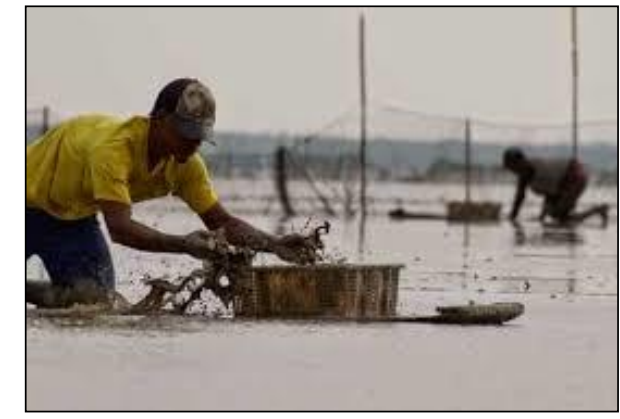

Gambar 4. Menongkah Kerang

(Sumber: https://www.cendananews.com, 2016)

Mereka menjelajah hamparan lumpur dengan tangan yang sigap, meraba-raba dan memungut kerang dari lumpur. Di atas lumpur, kerang-kerang akan memancarkan sinarnya saat diterpa cahaya lampu jika menongkah dilakukan di malam hari. Dari cahaya yang terpancar itulah menandakan di lokasi tersebut terdapat kerang. Namun, hasil tangkapan kerang para nelayan suku Duanu ditentukan oleh musim dan kondisi arah angin di laut, sehingga pada saat mencari kerang, para nelayan harus berpindah-pindah tempat. Kegiatan menongkah merupakan pekerjaan utama komunitas Duanu dan dilakukan secara tradisional. Aktivitas menongkah ini sudah dilakukan secara turun-temurun dan tidak bisa dipisahkan dari keseharian orang Duanu. Rutinitas mengambil kerang menggunakan tongkah yang telah menjadi tradisi masyarakat masih terpelihara dengan baik hingga kini. Konon, tidak ada warga Duanu yang tidak bisa menongkah. Mereka berselancar mencari kerang di hamparan pantai lumpur yang luas.

Kendati hamparan lumpur tempat berkembang biaknya biota laut berupa kerang serta jenis biota laut lainnya di pesisir laut Indragiri Hilir yang luasnya mencapai ribuan hektar, tetapi sumber mata pencarian suku Duanu ini terancam punah. Ini karena ulah tangan manusia yang ingin menghasilkan tangkapan kerang dengan cepat dan banyak, seperti menyondong atau menangguk kerang-kerang 
tersebut, sehingga semua kerang dari yang kecil sampai yang besar akan terangkat dari permukaan. Ada oknum nelayan yang tidak memperhatikan keseimbangan ekosistem di dalamnya yang menyebabkan pertumbuhan kerang semakin berkurang. Padahal, mencari kerang dengan cara menongkah menggunakan tangan yang dilakukan orang Duanu merupakan hal yang baik dan tidak merusak lingkungan. Mereka sadar, kerangkerang bersifat sensitif, jika tercemar sedikit saja, dari induk sampai anak kerang akan mati. Tentu saja hal ini membuat populasi kerang menurun drastis. Oleh sebab itulah warga Duanu tetap bertahan melakukan pencarian kerang secara tradisional. Namun, kelakukan oknum nakal ini telah merugikan banyak pihak, terutama masyarakat Duanu, yang menggantungkan hidupnya dengan cara menongkah. Jika hal ini didiamkan saja, sumber mata pencaharian suku Duanu yang sejak zaman nenek moyang telah mencari kerang di hamparan lumpur laut pesisir Indragiri tersebut, makin hari semakin terancam punah.

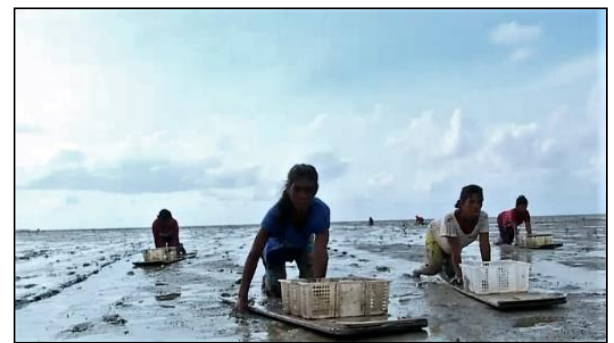

Gambar 5. Wanita Menongkah Kerang (Sumber: http://www.riaumagz.com, 2016)

Sejarah panjang tradisi menongkah ini, sejalan dengan kedatangan suku Duanu di pantai timur Sumatra. Kegiatan ini merupakan kearifan lokal suku Duanu dalam mencari kerang, tanpa mengganggu ekosistem di pantai, termasuk perkembangan kerang. Untuk mempertahankan eksistensi menongkah agar tidak punah kelestariannya, Sarpan Firmansyah memprakarsai sebuah kegiatan "Festival Menongkah." Festival ini, seperti yang disinyalir oleh Advetorial (2016), bahkan telah memecahkan rekor Muri (Museum Rekor-Dunia Indonesia) sebanyak dua kali dengan kategori peserta menongkah terbanyak (9 Juli 2008), mencapai 388 orang penongkah dan mandi lumpur terbanyak dengan jumlah 147 orang ( 7 Agustus 2016). Festival ini diselenggarakan di Pantai Bidari, Desa Tanjung Pasir, Kecamatan Tanah Merah, Kabupaten Indragiri Hilir. Panjang arena jalur menongkah dalam festival ini sekitar
20 km (dari Desa Tanjung Pasir dan berakhir di Desa Sungai Laut).

Festival Menongkah ini merupakan sebuah kegiatan budaya tradisional daerah untuk mendukung khazanah budaya bangsa serta sebagai ikon budaya daerah Indragiri Hilir, Riau. Selain itu, tujuan lainnya adalah untuk mempertahankan eksistensi budaya tradisional masyarakat Duanu, yakni menongkah, agar tidak punah dari kelestariannya. Dalam festival ini, selain menongkah, juga diadakan kegiatan satu malam bersama masyarakat Duanu. Dalam kegiatan itu, terdapat serangkaian acara lainnya, yaitu seminar tentang eksistensi menongkah, lomba buka kerang sebelah tangan, lomba menganyam tengkalang, lomba merajut belat, lomba berdenden, serta lomba permainan rakyat Duanu, seperti permainan seremban kulit kerang dan permainan congkak kulit kerang. Festival Menongkah, yang merupakan budaya tradisional, ini sudah mulai diketahui secara luas. Tentu saja kegiatan ini mendapat dukungan dari pemerintah setempat. Seperti yang diungkapkan Edi Syafwannur selaku Kepala Badan Pemberdayaan Masyarakat dan Pemerintah Desa (BPMPD) yang mewakili Bupati Indragiri Hilir, bahwa festival ini akan dijadikan agenda tahunan. Ditambahkan pula oleh H. Mukhtar, Kepala Dinas Kebudayaan dan Pariwisata Indragiri Hilir, bahwa pemerintah akan lebih mengembangkan potensi wisata tersebut karena di dalamnya terdapat berbagai pesan moral (Tim Redaksi Gurindam 12.com, 2012).

\section{Adat dan Kebiasaan Masyarakat Duanu: Merawat yang Tersisa}

Mengumpulkan data budaya tradisional suku Duanu saat ini, bukanlah pekerjaan yang mudah. Bila kita bertanya pada yang muda, banyak yang tidak tahu, sedangkan bila bertanya pada yang tua sudah banyak yang lupa atau hanya ingat sebagian. Dari kenyataan ini terlihat bahwa masyarakat suku Duanu telah mulai meninggalkan tradisi sastra mereka. Setelah dilakukan pendekatan untuk mengetahui alasan mereka meninggalkan tradisi, penulis melihat seolah-olah ada ketakutan untuk tetap menjalankan tradisi lisan tersebut. Ketakutan tersebut tidak terlalu jelas penyebabnya. Namun umumnya, alasan agamalah yang paling sering disebut. Hampir dapat dikatakan suku Duanu di Provinsi Riau seluruhnya menganut agama Islam. Anggapan mereka, tradisi lama itu salah menurut agama Islam. Sayangnya, tradisi yang sebenarnya tidak 
bertentangan dengan agama, menjadi ikut ditinggalkan juga. Padahal, melalui tradisi yang dilisankan tersebut dapat mewariskan nilai-nilai dari generasi ke Generasi (Zaini, 2014: 5-6). Berbicara tentang ketakutan, saat masyarakat Duanu belum memeluk agama Islam, mereka mempercayai kekuatan-kekuatan gaib. Mereka percaya benda-benda (pohon, laut, tanah, batu, dan lain-lain) memiliki kekuatan roh yang disebut mambang. Kekuatan gaib ini akan menjadi ancaman bagi kehidupan mereka jika mereka tidak menghormati atau tidak mematuhi pantangan tertentu. Dari hal ini muncul kekhawatiran yang terus tertanam pada diri mereka. Ketika telah memeluk agama Islam, kekhawatiran/ketakutan itu tetap muncul meski mereka mengaku sudah tidak percaya pada adanya kekuatan mambang itu. Dari perbincangan yang dilakukan, masyarakat Duanu sebenarnya memiliki tradisi/budaya yang sarat akan sastra lisan seperti mantra, cerita rakyat, pantun, dan nyanyian. Sangat disayangkan, bila sastra lisan yang bisa menjadi sumber untuk mengetahui kehidupan dan nilai-nilai masyarakat penuturnya di masa lampau ini hilang seluruhnya. Ibarat memungut remahremah roti, penulis berusaha mengumpulkan penggalan-penggalan tradisi lisan yang masih bisa diingat. Karena itu, data yang diperoleh tidak lengkap dan kurang otentik. Meski data ini dianggap tidak mencerminkan suku Duanu yang asli, tetapi inilah kenyataannya saat ini.

\section{Denden (Berdenden)}

Berdenden berarti bernyanyi dalam bahasa Duanu. Denden ini biasanya dinyanyikan untuk menidurkan anak. Selain itu, pada saat lain denden ini juga mereka nyanyikan seperti saat menongkah kerang, mengumpulkan ikan, atau sekadar mengisi waktu. Denden juga termasuk tradisi lisan yang sudah mulai ditinggalkan. Ibu-ibu tidak lagi mengantarkan anak mereka tidur dengan denden. Mereka telah menggantikannya dengan lagu-lagu masa kini. Inilah konsekuensi perkembangan zaman dan semakin terbukanya orang Duanu dengan kebudayaan lain.

Selain karena perkembangan zaman, denden juga ditinggalkan karena dianggap tidak sejalan dengan agama Islam. Isi syair denden mengandung unsur kepercayaan animisme, kepercayaan lama yang telah mereka tinggalkan. Isi denden beraneka ragam, antara lain "bujukan" orang Duanu terhadap para roh (mambang) untuk bersahabat dan tidak mengganggu selama mereka beraktivitas di laut. Dalam membujuk para mambang tersebut, orang Duanu menyebutkan kalau mereka orang Duanu dan para mambang bersaudara. Oleh sebab itu, sesama saudara sebaiknya tidak bermusuhan. Denden juga berisi cerita saat mereka beraktivitas di laut seperti mendayung perahu, mengembangkan layar, menangkap kerang, menurunkan belat ikan, atau menjaring udang.

Uniknya, denden orang Duanu ini meski dinyanyikan untuk mengantar tidur anak, tidak terdapat harapan orang tua ataupun nasihat kepada anaknya. Denden orang Duanu berisi kejadiankejadian di laut yang sehari-hari mereka alami. Tidak seperti nandung atau baghandu di daerah Indragiri Hulu dan Kampar yang isinya harapan/doa, nasihat, dan bujukan dari orang tua untuk anaknya. Perbedaan ini menunjukkan perbedaan kehidupan sehari-hari masyarakat penuturnya. Masyarakat lain yang mata pencariannya dari bercocok tanam atau berburu sambil mengumpulkan makanan di hutan mempunyai pembagian waktu untuk kegiatankegiatan tertentu. Mereka memiliki saat-saat tertentu untuk berladang, berburu, memasak, beristirahat, atau tidur. Orang Duanu berbeda. Dahulu, mereka hidup di perahu. Seluruh aktivitas sehari-hari mereka lakukan di atas perahu itu. Jadi, pembagian waktu untuk aktivitas sehari-hari menjadi tidak jelas. Mereka bisa menjaring ikan sambil menidurkan anak atau bermain bersama anak sambil menunggu belat. Oleh karena itu, denden orang Duanu memiliki perbedaan yang khas bila dibandingkan dengan nyanyian "nina bobo" masyarakat lain. Denden tidak dinyanyikan saat menidurkan anak saja. Namun, dendang ini bisa dinyanyikan kapan saja dan oleh siapa saja. Denden bisa berisi cerita mencari nafkah di laut atau pengajaran cara mencari ikan, membelat, menongkah, ataupun merawai.

Bentuk denden juga tidak ada patokan yang jelas. Bentuknya bisa berupa pantun atau dapat juga seperti puisi bebas. Rimanya juga tidak selalu terikat pada bentuk-bentuk tertentu. Pelantun denden sudah sangat susah ditemukan dalam kehidupan masyarakat Duanu. Seorang guru di SDN 011 Desa Concong Luar yang terdapat di seberang Desa Panglima Raja, Zaini Muchtar, kelahiran 1970, misalnya, merupakan satusatunya pelantun tradisi lisan denden di desa tersebut, setelah pelantun lainnya, Idris, sudah sakit-sakitan karena renta (Dinas Kebudayaan dan Pariwisata ["Denden," Oh "Denden"], 2013a: 23). 
Saat ini, denden hanya tinggal sebagai salah satu seni pertunjukan orang suku Duanu, serta pernah pula digelar dalam berbagai acara di Pekanbaru dan Tembilahan.

\section{Permainan Anak}

Permainan adalah sesuatu yang digunakan untuk menyenangkan hati, baik menggunakan alat ataupun tidak. Permainan anak adalah kegiatan bermain yang dilakukan oleh anak-anak tidak tertutup pula bagi orang dewasa yang dilakukan untuk mengisi waktu senggang. Di kediaman masyarakat suku Duanu, permainan anak ini kerap menggunakan kulit kerang, sebab sebagian besar mereka adalah nelayan yang mahir menangkap kerang. Dengan memberdayakan bahan sisa yang ada, mereka bisa menciptakan berbagai permainan yang bisa digunakan oleh anak-anak mereka. Permainan yang tercipta dengan menggunakan bahan sisa kerang tersebut, antara lain seremban kulit kerang, congkak kulit kerang, dan gasing kulit kerang.

\section{Seremban kulit kerang}

Permainan seremban adalah sebuah permainan yang biasanya menggunakan biji (asam, sawo, sirsak, dan sebagainya) atau uang logam yang digenggam, lalu dibuang ke atas, ditadah oleh punggung tangan, dilemparkan lagi ke atas, ditadah oleh telapak tangan, dan seterusnya. Sementara itu, permainan seremban kulit kerang menggunakan kulit kerang sebagai pengganti biji yang biasa dipakai anak-anak lain dalam bermain. Permainan tradisional ini bisa juga menggunakan bola. Kulit-kulit kerang dikumpulkan beberapa buah, sekitar enam kulit kerang. Lalu, kulit-kulit kerang itu diletakkan di lantai yang datar, kemudian bola dilantunkan ke lantai berulang kali. Tiap lantunan bola terjadi, anak mengambil satu kulit kerang dan disimpan dalam genggaman dan secara bersamaan juga menangkap bola yang dilantunkan tersebut. Hal ini dilakukan berulang, hingga kulit kurang di lantai tersebut habis. Setelah kulit kerang terkumpul dalam genggaman, anak kembali melantunkan bola dan meletakkan kulit-kulit kerang tersebut ke lantai kembali di sela-sela lantunan bola. Berikutnya, dalam tiap lantunan bola, anak mengambil dua-dua kulit kerang untuk kemudian menyimpannya dalam genggaman hingga kulit kerang di lantai habis. Kegiatan ini berulang hingga anak bisa menyimpan kulit kerang dalam genggaman dalam sekali angkut.

\section{Congkak kulit kerang}

Congkak adalah jenis permainan tradisional lainnya yang juga sering dimainkan oleh anakanak di waktu senggang. Permainan congkak ini disebut juga dakon di daerah Jawa. Permainan ini menggunakan wadah dari papan ada juga yang terbuat dari plastik berbentuk perahu yang berlubang-lubang. Di setiap lubang papan congkak diisi kulit kerang (bisa juga menggunakan biji-bijian dan sebagainya) sesuai dengan jumlah yang ditetapkan. Biasanya permainan ini dimainkan oleh dua orang, yang berada di sisi masing-masing papan congkak. Permaianan biasanya dimenangkan oleh anak yang berhasil mengumpulkan kulit kerang terbanyak.

\section{Gasing kulit kerang}

Gasing adalah alat permainan yang berbentuk bulat, memanjang atau pipih, dimainkan dengan dipusing atau diputar memakai tali yang dililitkan dan ditarik kuat-kuat. Permainan ini telah ada sejak zaman kesultanan Malaka, yang dimainkan oleh anak-anak maupun orang dewasa. Biasanya permainan ini dimainkan oleh laki-laki dengan beregu (Dinas Kebudayaan dan Pariwisata ["Permainan Anak: Gasing"], 2013b: 48). Di permukiman Duanu, gasing ini biasanya terbuat dari kulit kerang. Kulit kerang dilubangi di bagian tengah. Kemudian dua kulit kerang yang sudah dilubangi disatukan, diadu kedua punggungnya (dalam arah yang berlawanan), lalu dirajut menggunakan karet dan diikat. Apabila kedua sisi karet pengikat kulit kerang tersebut direnggangkan dan ditarik, gasing itu akan mengeluarkan bunyi. Semakin besar dan panjang bunyi gasing kulit kerang tersebut, berarti semakin bagus pula kualitas gasing yang mereka buat.

Permainan anak-anak ini merupakan permainan untuk mengisi waktu senggang. Waktu bermain biasanya pagi atau sore hari. Permainanpermainan ini bisa dilakukan oleh siapa saja, baik laki-laki maupun perempuan, dan tidak tertutup pula bagi orang dewasa yang sedang tidak bekerja. Permainan dengan menggunakan bahan sisa yang sudah tidak digunakan lagi ini merupakan suatu kegiatan yang penuh kreativitas. Tanpa menggunakan modal yang berarti, bisa tercipta sebuah permainan, yang selain berfungsi untuk mengisi waktu senggang, juga bisa merangsang jiwa sosial anak untuk dapat berbaur dengan 
teman sebaya. Selain itu, jiwa kompetitif anak juga bisa terasah.

Namun sayang, berbagai permainan tradisional ini sudah sangat jarang ditemukan dalam kehidupan masyarakat Duanu. Seiring perkembangan zaman, anak-anak kerap mengisi waktu dengan memainkan permainan modern. Dalam sebuah telepon genggam misalnya, tersedia permainan yang dapat menyita waktu anak, sehingga anak tidak lagi memiliki waktu bermain bersama teman-teman sebaya di luar rumah. Masing-masing telah disibukkan dengan peralatan canggih yang mereka miliki. Sebagai akibatnya, mental individualistis anak semakin meningkat. Anak pun menjadi kurang peduli dengan lingkungannya.

\section{Festival Menongkah sebagai Upaya Melawan Kepunahan Budaya dan Bahasa Duanu}

Bahasa merupakan alat ampuh bagi manusia untuk berhubungan dengan sesuatu di luar dirinya. Menggunakan bahasa, manusia mampu beradaptasi dengan lingkungannya. Bahasa memiliki peran penting bagi kehidupan manusia, baik secara lisan maupun tulis. Bahasa dapat mencerminkan cara pandang penuturnya terhadap dunia. Bahasa juga berfungsi sebagai jati diri bangsa, kebanggaan nasional, sarana pemersatu berbagai suku bangsa, serta sarana komunikasi antardaerah dan antarbudaya daerah. Agus Sri Danardana ("Menyongsong Peringatan Hari Bahasa Ibu", 2011a: 68-69) berpendapat lahirnya manusia Indonesia yang cerdas dan kompetitif sesungguhnya dapat dimulai dari penanganan masalah kebahasaan. Dalam konteks Indonesia, manusia yang cerdas itu setidaknya dapat digolongkan ke dalam tiga kompetensi: lokal, nasional, dan internasional. Jika dikaitkan dengan kemampuan berbahasa, dapat dikatakan bahwa manusia cerdas berkompetensi lokal sesungguhnya cukup menguasai bahasa daerah tempat tinggalnya. Ia akan menjadi manusia cerdas tingkat nasional jika menguasai pula bahasa Indonesia. Begitu seterusnya, ia baru akan menjadi manusia cerdas berkompetensi internasional jika menguasai pula bahasa asing. Dengan demikian, manusia Indonesia yang cerdas dan kompetitif itu adalah manusia Indonesia yang berjati diri. Pada tingkat nasional, ia dapat dikenali kelokalannya. Pada tingkat internasional, ia dapat dikenali keindonesiaannya.

Akan tetapi, sejumlah bahasa di dunia terancam punah. Sebagian besar bahasa yang terancam punah itu merupakan bahasa etnik minoritas. Hal ini disebabkan oleh beberapa hal, antara lain: semakin meningkatnya mobilitas atau pengaruh media; urbanisasi dan perkawinan antaretnis; merasa rendah diri berbahasa daerah; dan sebagainya. Padahal, daerah yang kehilangan bahasa lokalnya, sekaligus akan kehilangan identitas kesukuannya. Untuk itu, perlu adanya revitalisasi bahasa sebagai upaya untuk menghidupkan kembali bahasa daerah tersebut. Indonesia, dengan keragaman bahasa, memiliki bahasa nasional yang bisa menjadi bahasa pemersatu setiap suku, ras, dan kebudayaan di Indonesia. Persatuan bangsa Indonesia bukan terbentuk dari keseragaman, tetapi terbentuk dari keanekaragaman. Semboyan "Bhineka Tunggal Ika" tidak hanya mencakup suku, ras, dan agama saja, tetapi juga mencakup bahasa, karena pada hakikatnya bahasa melekat pada diri manusia. Sementara itu, manusia merupakan pelaku kebudayaan.

Dalam tulisannya berjudul "Peranan Bahasa dalam Persatuan Bangsa," Amani (2012) menyebutkan keberagaman ini merupakan aset kemanusiaan yang tidak ternilai harganya. Sebab, menurutnya dengan mengutip pernyataan Cueller (1996) bahwa setiap usaha yang memaksakan keseragaman atas kebinekaan merupakan tandatanda awal kematian keberagaman yang dimiliki suatu bangsa merupakan warna-warni kehidupan. Dengan demikian, apabila satu saja bahasa yang ada hilang di muka bumi, telah terjadi pemiskinan (improverishment) akan sumber pengetahuan dan pikiran masyarakatnya. Bahasa daerah memiliki peran dan fungi yang besar terhadap keberlangsungan suatu negara. Apabila bahasa punah, kearifan lokal pun ikut punah.

Bahasa Duanu yang hidup dan berkembang di perairan Kabupaten Indragiri Hilir, Provinsi Riau ini, berada pada posisi kritis karena berada di ambang kepunahan. Suku Laut ini menyebar di beberapa desa di Kabupaten Indragiri Hilir. Kabupaten Indragiri Hilir yang terletak di pantai timur Pulau Sumatra merupakan gerbang selatan Provinsi Riau, dengan luas wilayah 18.812,97 km² yang terdiri atas luas daratan $11.605,97 \mathrm{~km}^{2}$, luas perairan laut $6.318 \mathrm{~km}^{2}$, dan luas perairan umum $888,97 \mathrm{~km}^{2}$ serta memiliki garis pantai sepanjang 339,5 km. Kabupaten ini berbatasan sebelah utara dengan Kabupaten Pelalawan, sebelah selatan berbatasan dengan Kabupaten Tanjung Jabung Provinsi Jambi, sebelah barat berbatasan dengan Kabupaten Indragiri Hulu, dan 
sebelah timur berbatasan dengan Provinsi Kepulauan Riau (Pemerintah Kabupaten Indragiri Hilir, 2013). Menurut tuturan Sarpan Firmansyah yang ditemui pada tanggal 17 Juni 2013 di Pekanbaru, masyarakat Duanu di Riau berjumlah sekitar 15.000 jiwa. Jumlah ini sangat kecil, bahkan tidak mencapai tiga persen dari seluruh jumlah penduduk Kabupaten Indragiri Hilir, yaitu 683.354 jiwa. Mereka tersebar di 13 desa pada 7 kecamatan, Kabupaten Indragiri Hilir. Desa tersebut adalah Desa Belaras dan Desa Bekawan (Kecamatan Mandah), Desa Kuala Selat dan Kelurahan Bandar Sri Gemilang (Kecamatan Kateman), Desa Concong Luar dan Desa Panglima Raja (Kecamatam Concong), Desa Sungai Belah dan Desa Perigi Raja (Kecamatan Kuala Indragiri), Desa Tanah Merah, Desa Tanjung Pesisir, dan Desa Sungai Laut (Kecamatan Tanah Merah), Desa Kuala Patahparang (Kecamatan Sungai Batang), dan Desa Pulau Ruku (Kecamatan Reteh).

Dari jumlah yang sedikit itu, hanya generasi tua yang berusia di atas 40 tahun saja bisa berbahasa Duanu. Mereka memang masih menggunakan bahasa Duanu dalam komunikasi intrasuku dan sesama generasi tua, tetapi mereka menggunakan bahasa Melayu ketika berkomunikasi dengan anak-anak mereka. Hanya sebagian kecil saja dari generasi muda berusia di bawah 40 tahun memahami bahasa ibu mereka. Hal ini merupakan penanda bahwa eksistensi bahasa Duanu sudah sangat mencemaskan. Bahasa Duanu, yang serumpun dengan Bahasa Melayu dengan jarak kosakata di atas $80 \%$ baik Bahasa Melayu Daratan maupun Bahasa Melayu Kepulauan (Riswara, Rachmawati, Abidin, \& Raja Saleh, 2013: 40) sudah berada di ambang kepunahan. Hal ini disebabkan oleh beberapa faktor. Pertama, semakin meningkatnya mobilitas atau pengaruh media di era globalisasi ini.

Perkembangan zaman mengakibatkan rasa rendah diri orang Duanu untuk menjadi diri sendiri yang seharusnya bangga pada puaknya. Sebagian besar masyarakat suku ini merasa lebih nyaman disebut orang Melayu daripada orang laut. Rasa rendah diri dan malu ini menjadi faktor lain orang Duanu enggan berbahasa ibu. Keengganan ini berlarut dan menyebabkan orang Duanu tidak meneruskan bahasanya ke anak cucu. Urbanisasi dan perkawinan antaretnis menjadi faktor berikut atas punahnya bahasa Duanu. Jika kedua orang tua berkomunikasi tanpa menggunakan bahasa Duanu dalam keseharian, tentu saja mata rantai penggunaan bahasa ini akan terputus.

Bahasa yang unik dan spesifik ini dianggap aneh dan tidak populer bagi penutur muda. Padahal beberapa lemanya sangat dekat dengan bahasa Melayu, seperti dapu 'dapur,' kama 'kamar,' bungu 'bunga,' munum 'minum,' telingu 'telinga,' matu 'mata,' dan sebagainya. Hal ini disebabkan orang Duanu juga termasuk Melayu Tua atau Proto Malay. Memang, beberapa kata sangat berbeda, seperti ditak 'kecil,' tukul 'pemukul,' dabi 'perempuan,' ribut 'hujan,' kulu 'kepala,' rat 'banyak,' lepu 'gigi,' dan sebagainya, tetapi justru itulah letak keunikan dan membedakannya dengan bahasa Melayu (Danardana et al., 2013: 53). Sementara itu, akulturasi dan perkawinan campuran yang terjadi tidak dapat dihindari. Orang-orang yang biasa hidup di perahu, berpindah-pindah sebagai pengembara di laut ini, kerap merasa jauh dari peradaban manusia pada umumnya. Maka, ketika mereka berusaha membuka diri, bermukim dan menetap di darat, menyebabkan mereka berbaur dengan masyarakat lainnya, seperti orang Melayu, Bugis, Banjar, Cina, dan lain-lain. Mereka beradaptasi dengan lingkungan, sehingga akulturasi pun terjadi. Orang Duanu yang melakukan perkawinan campuran dengan suku lainnya adalah sebagai bentuk keterbukaan mereka. Namun, ternyata hal ini ikut menggerus bahasa mereka. Banyak dari mereka yang tidak menuturkan bahasa Duanu lagi, karena salah satunya bukanlah orang Laut. Anak-anak mereka tidak lagi menggunakan bahasa tersebut dalam keseharian. Akibatnya, hanya orang-orang tua saja yang masih menggunakan dan memahami bahasa Duanu, sementara yang lainnya hanya mendengar sesekali, mengerti tetapi tidak bisa mengucapkannya, bahkan ada pula yang tidak memahaminya sama sekali, meskipun keturunan Duanu.

Tidak ingin dianggap sebagai orang pinggiran dan terbelakang lagi, orang Duanu mengikuti proses modernisasi. Tidak sedikit dari mereka yang mulai tidak hanya bergantung kepada laut, padahal konon, laut dipercayai sebagai sumber penghidupan sepanjang usia. Suku yang merupakan bagian dari sejarah Indonesia sebagai negara kepulauan ini, mulai meninggalkan kebudayaan nenek moyang. Banyak dari mereka bekerja sebagai buruh, kuli, dan petani. Beberapa ada yang menjadi pegawai negeri dan harus pindah ke ibukota kabupaten. Ternyata, hidup 
berbaur dengan suku lain menyebabkan mereka jarang berbahasa Duanu. Dalam pergaulan seharihari, generasi muda dan bahkan orang-orang tua menggunakan bahasa Indonesia dan Melayu dalam berkomunikasi. Maka, lambat-laun, bahasa ibu mereka pun mulai terlupakan.

Fetival Menongkah, diyakini, merupakan salah satu upaya agar suku bangsa Duanu ini tidak lenyap oleh peradaban. Festival Menongkah, sebagai sebuah ajang kebudayaan, menampilkan berbagai kebudayaan masyarakat Duanu, baik menongkah sebagai penopang kehidupan mereka, maupun sastra dan budaya suku Duanu serta permainan rakyat yang sudah mulai ditinggalkan dalam keseharian mereka. Kebudayaan, sebagai salah satu aspek pariwisata, ikut berdampak positif sejalan dengan dinamika pariwisata. Dinamika tersebut berkembang karena kebudayaan memegang peranan penting bagi pembangunan berkelanjutan pariwisata. Begitu pula sebaliknya, pariwisata pun memberikan peranan dalam merevitalisasi kebudayaan. Ciri positif dinamika tersebut diperlihatkan dengan pola kebudayaan yang mampu meningkatkan pariwisata dan pariwisata juga mampu memajukan kebudayaan (Geriya, 1996: 51).

Bahasa, yang berfungsi sebagai pengungkap, pelestari, dan pewaris budaya bangsa, memiliki peranan penting dalam festival kebudayaan ini. Bahasa sebagai suatu sistem komunikasi adalah bagian dari sistem kebudayaan. Bahasa terlibat dalam semua aspek kebudayaan, karena kebudayaan manusia tidak dapat terjadi tanpa adanya bahasa. Bahasa inilah yang memungkinkan terbentuknya kebudayaan. Bahasa sebagai suatu sistem komunikasi akan mempunyai makna hanya dalam sebuah kebudayaan yang mewadahinya. Artinya, untuk bisa memahami suatu bahasa, setidaknya harus mengerti kebudayaannya. Demikian sebaliknya, untuk memahami kebudayaan suatu daerah, akan lebih sempurna apabila memahami bahasanya.

Hal inilah yang mendasari pemikiran diselenggarakannya Festival Menongkah. Pada rangkaian kegiatan festival, terdapat beragam aktivitas yang menyangkut kebudayaan masyarakat Duanu. Harapan dari kegiatan ini adalah aktivitas tradisional yang diselenggarakan tersebut dapat menjadi sarana yang ampuh dan efektif untuk mendorong masyarakat agar menggiatkan kembali berbagai kebudayaan yang nyaris punah serta memikirkan kembali penggunaan bahasa daerah mereka.

\section{Industri Kreatif}

Istilah ekonomi kreatif berkembang dari konsep modal berbasis kreativitas yang dapat berpotensi meningkatkan pertumbuhan ekonomi di suatu daerah. Negara-negara maju mulai menyadari bahwa saat ini sudah tidak bisa mengandalkan bidang industri saja sebagai sumber ekonomi di negaranya. Akan tetapi, mereka harus lebih mengandalkan sumber daya manusia yang kreatif karena kreativitas manusia berasal dari daya pikirnya yang menjadi modal dasar untuk menciptakan inovasi dalam menghadapi daya saing atau kompetisi pasar yang semakin besar.

Rochmat Aldy Purnomo (2016) mengutip dari "Cetak Biru Ekonomi Kreatif 2025" bahwa ekonomi kreatif merupakan suatu penciptaan nilai tambah (ekonomi, sosial, budaya, lingkungan) berbasis ide yang lahir dari kreativitas sumber daya manusia (orang kreatif) dan berbasis pemanfaatan ilmu pengetahuan, termasuk warisan budaya dan teknologi. Terdapat tiga hal pokok yang menjadi dasar dari ekonomi kreatif, antara lain kreativitas, inovasi, dan penemuan (Purnomo, 2016: 6-10). Dengan adanya konsep ekonomi kreatif, sisi industrialisasi pun bisa dikembangkan ke arah industri kreatif. Industri kreatif merupakan industri yang menghasilkan ouput dari pemanfaatan kreativitas, keahlian, dan bakat individu untuk menciptakan nilai tambah, lapangan kerja, dan peningkatan kualitas hidup. Ekonomi kreatif sering dilihat sebagai sebuah konsep yang memayungi juga konsep lain yang populer di awal abad ke-21 ini, yaitu industri kreatif.

Industri kreatif di Indonesia mengacu kepada pengertian industri kreatif yang tercatat dalam Creative Industries Task Force, yakni "Creative Industries as those industries which have their origin in individual creativity, skill \& talent, and which have a potential for wealth and job creation through the generation and exploitation of intellectual property and content" (Department of Culture, Media, and Sport [DCMS] United Kingdom).

Definisi Creative Industries Task Force ini sejalan definisi industri kreatif yang tertulis dalam buku Rencana Pengembangan Ekonomi Kreatif Indonesia 2009-2015 yang dikeluarkan Kementerian Perdagangan RI (2008) yakni "Industri kreatif berasal dari pemanfaatan kreativitas, keterampilan serta bakat individu untuk menciptakan kesejahteraan serta lapangan 
pekerjaan melalui penciptaan dan pemanfaatan daya kreasi dan daya cipta individu tersebut."

Hingga kini, Pemerintah Indonesia telah mengidentifikasi lingkup industri kreatif ke dalam 15 subsektor, antara lain: (1) periklanan (advertising), (2) arsitektur, (3) pasar barang seni, (4) kerajinan (craft), (5) desain, (6) pakaian (fashion), (7) video, film, dan fotografi, (8) permainan interaktif (game) yang mengandung unsur edukasi, (9) musik, (10) seni pertunjukan (showbiz), (11) penerbitan dan percetakan, (12) layanan komputer dan piranti lunak (software), (13) televisi dan radio (broadcasting), (14) riset dan pengembangan (research and development), dan (15) kuliner (Purnomo, 2016:16-21).

Industri budaya memang lebih digerakkan oleh para pemodal/perusahaan besar yang mencari keuntungan melalui sistem industri budaya dengan cara memproduksi dan mendistribusikan produk budaya secara nasional (atau bahkan internasional) yang di dalamnya terdapat keseluruhan organisasi yang terlibat dalam proses penyaringan produk dan ide baru yang berasal dari personel kreatif yang berada dalam level subsistem. Sementara, konsep industri kreatif menekankan pada tingkatan yang lebih luas dari aktivitas yang termasuk di dalamnya industri budaya dan semua produk kultural atau artistik, baik yang bersifat live (seperti seni pertunjukan) maupun yang diproduksi oleh unit-unit individual. Maka, industri kreatif secara umum mencakup penyediaan produk atau jasa yang memuat elemen-elemen substansial dari usaha kreatif dan artistik (Anoegrajekti, 2013).

\section{Mendayagunakan Budaya dan Bahasa sebagai Sumber Industri Kreatif}

Undang-Undang RI Nomor 10 Tahun 2009 tentang Kepariwisataan mengamanatkan bahwa sumber daya dan modal kepariwisataan dapat dimanfaatkan secara optimal melalui penyelenggaraan kepariwisataan yang ditujukan untuk meningkatkan pendapatan nasional, memperluas dan memeratakan kesempatan berusaha dan lapangan kerja, mendorong pembangunan daerah, memperkenalkan dan mendayagunakan daya tarik wisata dan destinasi di Indonesia, serta memupuk rasa cinta tanah air, dan mempererat persahabatan antarbangsa. Pengembangan kepariwisataan di Indragiri Hilir diharapkan dapat memenuhi target ekonomi kreatif dengan industri kreatif sebagai subsistemnya. Untuk itu, strategi kebijakan yang perlu dikembangkan adalah memaksimalkan kontribusi sumber daya pariwisata yang mampu memberikan nilai tambah secara ekonomi, dan berupaya menelusuri potensi-potensi ekonomi baru yang belum tergali (Widiatedja, 2011: 28).

Salah satu potensi objek dan daya tarik wisata yang baru di Indragiri Hilir adalah Festival Menongkah. Festival Menongkah adalah produk budaya komunitas adat terpencil setempat, yaitu suku Duanu, yang mempersembahkan beraneka budaya tradisional yang turun-temurun dari leluhur mereka. Festival Menongkah ini dapat dimanfaatkan sebagai sumber daya dan modal kepariwisataan dengan cara mentransformasikan ke dalam bentuk produk yang dapat dijual. Dengan demikian, sumber daya yang ada dalam festival ini mampu memberikan nilai tambah secara ekonomi sebagai potensi ekonomi baru yang belum pernah tergali sebelumnya.

Sebagai produk budaya unggul, sumber daya dalam suku bangsa Duanu tersebut dapat dimaksimalkan dengan pengembangan dan penguatan industri kreatif. Seperti yang dicatat Purnomo (2016), terdapat lima belas subsektor dalam lingkup industri kreatif, yakni (1) periklanan (advertising), (2) arsitektur, (3) pasar barang seni, (4) kerajinan (craft), (5) desain, (6) pakaian (fashion), (7) video, film, dan fotografi, (8) permainan interaktif (game) yang mengandung unsur edukasi, (9) musik, (10) seni pertunjukan (showbiz), (11) penerbitan dan percetakan, (12) layanan komputer dan piranti lunak (software), (13) televisi dan radio (broadcasting), (14) riset dan pengembangan (research and development), dan (15) kuliner (Purnomo, 2016: 16-21). Untuk mentransformasi sumber daya yang dimiliki suku Duanu menjadi produk yang dapat dikonsumsi pendatang dengan memanfaatkan pasar barang seni, kerajinan, pakaian, video, film, dan fotografi, musik, seni pertunjukan, penerbitan dan percetakan, serta kuliner dengan menggunakan media bahasa (Melayu Duanu) sebagai penyampai kebudayaannya, misalnya penamaan produk yang dihasilkan harus menggunakan bahasa Duanu.

Pasar barang seni merupakan kegiatan kreatif yang berkaitan dengan perdagangan barang-barang asli, unik, dan langka, serta memiliki nilai estetika seni dan sejarah yang tinggi melalui lelang, galeri, toko, pasar swalayan, dan internet, meliputi barang-barang musik, percetakan, kerajinan, automobile, dan film. Untuk mengangkat suku Duanu ke permukaan, 
yang dapat dilakukan dalam hal ini adalah membangun sebuah museum menongkah di Indragiri Hilir. Museum ini bermanfaat sebagai tempat yang menyediakan berbagai literatur dan dokumentasi yang menerangkan banyak hal mengenai tradisi puak Proto Melayu tersebut. Selain itu, dapat pula mendirikan tugu menongkah di Desa Tanjung Pasir, seperti yang dicita-citakan Sarpan Firmansyah. Untuk itu, ia bahkan telah sampai ke Kedutaan Besar Jerman di Jakarta, untuk memperjuangkan agar tradisi menongkah ini bisa mengikuti ajang Festival Lumpur di Jerman. Lelaki ini juga bertekad mendaftarkan menongkah sebagai hak kekayaan intelektual suku Laut (Duanu) ke Komite Badan Warisan Dunia, UNESCO.

Produk lain yang bisa dihasilkan adalah kerajinan. Kerajinan (craft) merupakan kegiatan kreatif yang berkaitan dengan kreasi, produksi, dan distribusi produk yang dibuat atau dihasilkan oleh tenaga pengrajin, yang biasanya berawal dari desain awal sampai proses penyelesaian produknya. Untuk menghasilkan kerajinan, suku Duanu bisa memanfaatkan kulit kerang sebagai bahan bakunya. Bentuk kerajinan yang bisa dihasilkan antara lain gantungan kunci, pigura foto, kotak tisu, dan lain-lain. Untuk pakaian (fashion), yakni kegiatan kreatif yang terkait dengan kreasi desain pakaian, desain alas kaki, dan desain aksesoris mode lainnya, masyarakat setempat dapat memproduksi baju kaos maupun kemeja yang menggunakan pantun, pepatah, maupun syair berbahasa Duanu. Sebagai contoh, beberapa syair berikut ini bisa dirancang untuk pakaian tersebut.

\section{Du belas dayung ke Jambi Putik nenas dalam kebun Adik piak belah kambang Sedato siang berpanis Bereng berimbun}

'Dua belas dayung ke Jambi Putik nenas di dalam kebun Adik tidak membelah kambang sewaktu siang berpanas malam berembun'

Tesungku enap di luan lancu

Tegolek-golek di tengah tuban Teputih matu dang nei bitan jalo Oh, enap turun neh le Bebelat dekat sangu pangkoh Ikin rat dalam belat piak tetampung lum 'tersungkur di depan lancu terbaring-baring di tengah tuban terputih mata yang duduk di depan perahu oh, turunkanlah layar berbelat di daerah Sangu Pangkoh ikan banyak di dalam belat tidak tertampung'

\section{Piak Duanu lap ne dolak}

'Tidaklah dia seorang Duanu kalau hilang di laut'

Kegiatan menongkah dapat pula dipublikasikan melalui video. Kegiatan kreatif yang terkait dengan kreasi produksi video, film, dan jasa fotografi, serta distribusi rekaman video dan film ini dapat pula mengangkat cerita rakyat yang pernah hidup di masyarakat menjadi film. Foto-foto saat Festival Menongkah pun bisa didokumentasikan, lalu disebarkan melalui berbagai media. Foto-foto ini pun bisa dijadikan kartu pos, poster, dan sebagainya.

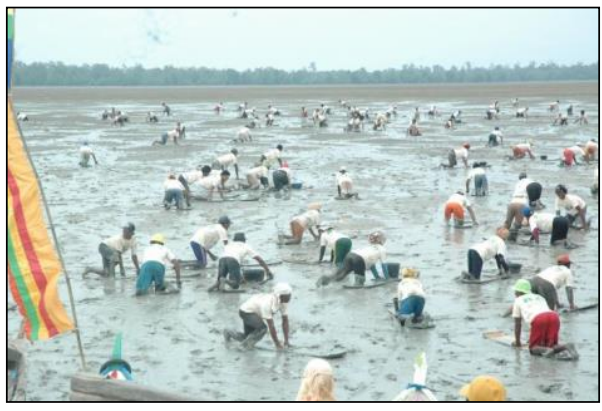

Gambar 6. Festival Menongkah

(Sumber: http://riauone.com/riau/, 2016)

Kegiatan berdenden bisa dijadikan produk di bidang musik. Kegiatan kreatif yang berupa kegiatan dengan kreasi atau komposisi, pertunjukkan, reproduksi, dan distribusi dari rekaman suara ini dapat membantu revitalisasi budaya dan bahasa sekaligus. Dengan pengemasan yang menarik, hasil rekaman lagu ini bisa dimuat di cakram padat dan dipasarkan. Selain itu, hasil rekaman juga bisa diunggah ke media internet. Berdenden juga dapat dijadikan ajang pertunjukan (showbiz). Dibantu dengan musik yang apik, desain dan pembuatan busana pertunjukan yang menarik, tata panggung dan pencahayaan yang tidak membosankan, tentu saja membuat pertunjukan berdenden ini akan banyak diminati. Pertunjukan bisa saja digelar di saat Festival Menongkah berlangsung maupun di luar kegiatan itu. Jika memang menarik, tidak tertutup kemungkinan bahwa pertunjukan ini akan tampil 
di luar Indragiri Hilir, sehingga tradisi ini bisa dikenal masyarakat luas.

Hal yang paling menarik dan disukai banyak orang adalah kuliner. Kegiatan kreatif dengan usaha inovatif yang menawarkan produkproduk kuliner yang menarik, mulai dari penyajian, cara pembuatan, sampai dengan komposisi makanan atau minuman yang disajikan merupakan bisnis yang menuntut kombinasi sektor inovasi dan kreasi ke dalam makanan dan minuman. Bagi masyarakat Duanu yang bergelut dengan hasil laut setiap harinya, terutama kerang, dapat menjadikan hasil laut ini sebagai bahan makanan yang unik dan tentu saja lezat. Misalnya, masyarakat bisa membuat sebuah tempat makan yang meyajikan makanan serba kerang, seperti sate, sup, tongseng, dan sebagainya. Untuk merevitalisasi bahasa Duanu, setiap masakan tersebut harus diberi nama dengan menggunakan bahasa Duanu. Untuk mengantisipasi punahnya kerang akibat ulah tangan-tangan yang tidak bertanggung jawab, perlu adanya budidaya kerang, yang akan memiliki manfaat besar bagi suku Duanu. Jika hal ini dikembangkam oleh pemerintah, produksi kerang tidak akan pernah putus dan tetap terjaga. Para nelayan tidak perlu lagi berpindah-pindah tempat untuk mencari kerang. Selain itu, untuk menyelamatkan suku Duanu dari kepunahan serta lajunya perkembangan zaman, perlu adanya aturan-aturan baku yang dapat mengangkat hak-hak masyarakat suku Duanu, tentang hamparan lumpur laut ulayat masyarakat Duanu tersebut. Dengan adanya pengakuan atas hak masyarakat Duanu, tentu akan lebih memudahkan pemerintah dalam memperhatikan kesejahteraan masyarakat Duanu.

Apabila semua pihak, baik pemerintah maupun masyarakat, dapat bekerja sama, apa yang telah dirancang sebagai penopang industri kreatif ini akan memberikan dampak posisif, khususnya pada revitalisasi budaya dan bahasa Duanu. Festival Menongkah memiliki banyak potensi, apalagi jika dimanfaatkan secara optimal. Kegiatan ini selain untuk mengembangkan potensi wisata dan menghasilkan devisa, tentu juga melestarikan bahasa dan budaya puak Duanu. Upaya ini akan mengangkat ke permukaan, sehingga suku Duanu tidak saja dikenal secara nasional, tetapi juga memiliki nama di mata dunia.

\section{KESIMPULAN}

Suku Duanu, kaum minoritas yang populasi penduduknya tidak lebih dari tiga persen penduduk Kabupaten Indragiri Hilir, Riau, memiliki bahasa yang berada dalam kondisi yang mencemaskan. Masyarakat Duanu yang tersebar di tiga belas desa pada tujuh kecamatan di Kabupaten Indragiri Hilir tersebut, yaitu Desa Belaras dan Desa Bekawan (Kecamatan Mandah), Desa Kuala Selat dan Kelurahan Bandar Sri Gemilang (Kecamatan Kateman), Desa Concong Luar dan Desa Panglima Raja (Kecamatam Concong), Desa Sungai Belah dan Desa Perigi Raja (Kecamatan Kuala Indragiri), Desa Tanah Merah, Desa Tanjung Pesisir, dan Desa Sungai Laut (Kecamatan Tanah Merah), Desa Kuala Patahparang (Kecamatan Sungai Batang), dan Desa Pulau Ruku (Kecamatan Reteh), hanya sebagian kecil saja yang masih menggunakan bahasa ibu mereka. Sebagian besar generasi muda yang berusia di bawah 40 tahun sudah tidak bisa berbahasa bahkan memahami bahasa Duanu.

Terdapat beberapa faktor yang mempengaruhi suku Duanu ini tidak lagi menggunakan bahasa daerahnya, yaitu semakin meningkatnya mobilitas atau pengaruh media; urbanisasi dan perkawinan antaretnis; merasa rendah diri berbahasa daerah; dan sebagainya. Untuk itu, Sarpan Firmansyah Ketua Kerukunan Keluarga Besar Masyarakat Duanu Riau memprakarsai sebuah kegiatan yang diyakini bisa membantu mengungkap serta melestarikan bahasa dan kebudayaan Duanu, yaitu Festival Menongkah. Festival Menongkah merupakan kegiatan budaya tradisional daerah yang mendukung khazanah budaya bangsa, khususnya masyarakat Duanu. Dalam festival ini, yang dilombakan bukan hanya menongkah, tetapi juga berbagai kebudayaan dan permainan tradisional. Hal ini merupakan salah satu strategi dalam upaya melawan kepunahan bahasa Duanu. Namun, yang terjadi saat ini, Festival Menongkah masih bersifat perayaan dan kesenangan sesaat. Potensi yang ada di dalamya belum tergali secara optimal. Apabila Festival Menongkah ini dapat dimanfaatkan secara maksimal, berbagai tradisi budaya Duanu yang nyaris hilang dari muka bumi bisa dipertahankan, bahkan digiatkan kembali. Begitu pula halnya dengan bahasa yang berada di ambang kepunahan. Sebagai media penyampai kebudayaan, bahasa Duanu pun turut terevitalisasi. Masyarakat pun semakin makmur sebab berbagai produk industri kreatif turut menopang kehidupan mereka. Dengan demikian, puak Duanu akan terus ada di Indragiri Hilir dan dikenal pula oleh masyarakat di luarnya. 


\section{Ucapan Terima Kasih}

Penulis mengucapkan terima kasih kepada Bapak Sarpan Firmansyah yang telah bersedia menceritakan berbagai kisah kehidupan suku Duanu dan menjawab pertanyaan yang penulis ajukan. Ucapan terima kasih juga penulis sampaikan kepada keluarga besar Bapak Sadin di Desa Sungai Laut dan keluarga Bapak Azwar di Desa Patahparang yang telah memperbolehkan menumpang bermalam-malam sehingga penulis bisa mengetahui kehidupan suku Laut. Penulis juga mengucapkan terima kasih kepada Dewan Redaksi Kapata Arkeologi yang menerbitkan tulisan ini.

$* * * * *$

\section{DAFTAR PUSTAKA}

Abidin, Z. (2014). Kekerabatan Bahasa Akit dan Duanu: Kajian Leksikostatistik. Madah, 5(1), 3954.

Advetorial. (2016). 7 Agustus, Dispora Inhil Gelar Festival Menongkah di Pantai Bidari. Retrieved from http://riauone.com/riau/7-Agustus-Dispora-Inhil-Gelar-Festival-Menongkah-diPantai-Bidari

Al-Ma'ruf, A. I. (2015). Pengembangan Sastra sebagai Industri Kreatif: Studi Kasus Novel Laskar Pelangi Karya Andrea Hirata. In Seminar Nasional Sastra, Pendidikan Karakter dan Industri Kreatif (pp. 12-25). Surakarta.

Amani, A. F. (2012). Peranan Bahasa dalam Persatuan Bangsa. Retrieved

from http://m.facebook.com/notes

Anoegrajekti, N. (2013). Sastra Lokal dan Industri Kreatif: Revitalisasi Sastra dan Budaya Using. Atavisme Jurnal Ilmiah Kajian Sastra, 16(2), 183193.

Anoegrajekti, N., Setyawan, I., Saputra, H. S. P., \& Macaryus, S. (2015). Perempuan Seni Tradisi dan Pengembangan Model Industri Kreatif Berbasis Seni Pertunjukan. Karsa, 23(1), 81-99.

Danardana, A. S. (2011a). Menyongsong Peringatan Hari Bahasa Ibu. In Anomali Bahasa. Pekanbaru: Palagan Press.

Danardana, A. S. (2011b). Pemertahanan Bahasa Melayu Riau. In Anomali Bahasa. Pekanbaru: Palagan Press.

Danardana, A. S., Wahyuni, D., Sarmianti, \& Diandini, R. (2013). Duanu Menongkah Resah. Pekanbaru: Palagan Press.

Departemen Pendidikan Nasional. (2008). Kamus Besar Bahasa Indonesia (IV). Jakarta: Gramedia Pustaka Utama.

Dinas Kebudayaan dan Pariwisata. (2013a). "Denden"
Oh "Denden." Citra Riau, Art Edition Art Edition.

Dinas Kebudayaan dan Pariwisata. (2013b). Permainan Anak: Gasing. Citra Riau, Art Edition.

Endraswara, S. (2012). Metodologi Penelitian Kebudayaan. Yogyakarta: Gadjah Mada University Press.

Geriya, W. (1996). Hubungan dan Permasalahan antara Pariwisata, Kebudayaan, dan Bahasa. In Pariwisata dan Dinamika Kebudayaan Lokal, Nasional, Global: Bunga Rampai Antropologi Pariwisata. Denpasar: Upada Sastra.

Mahyarni, Meflinda, A., Bustam, N., \& Tanjung, H. (2015). Mapping dan Strategi Pengembangan Potensi Ekonomi Berbasis Budaya Lokal di Provinsi Riau. Jurnal Aplikasi Manajemen, 13(4), 620-633.

Nyoman, I. S., \& Wayan, I. C. (2014). Pendayagunaan Folklor sebagai Sumber Ekonomi Kreatif di Daerah Tujuan Wisata Bali. Atavisme, 17(1), 7183.

Pemerintah Kabupaten Indragiri Hilir. (2013). Kabupaten Indragiri Hilir. Retrieved from http://www.inhilkab.go.id

Purnomo, R. A. (2016). Ekonomi Kreatif Pilar Pembangunan Indonesia, Indonesia. Retrieved from www.nulisbuku.com

Riswara, Y., Rachmawati, R., Abidin, Z., \& Raja Saleh. (2013). Peta dan Kekerabatan Bahasa-Bahasa Komunitas Adat Terpencil di Riau. Pekanbaru: Palagan Press.

Saksono, H. (2012). Ekonomi Kreatif: Talenta Baru Pemicu Daya Saing Daerah. Jurnal Bina Praja, 4(2), 93-104.

Suardina, I. W. (2011). Wacana Ekonomi Kreatif (Refleksi Sastra Lisan dan Tulis di Bali). Atavisme, 14(2), 204-213.

Susanti, N., \& Ichsani, S. (2012). Industri Kreatif Memerlukan Banyak Promosi. In Seminar Nasional Kewirausahaan dan Inovasi Bisnis II (pp. 441-449). Jakarta: Universitas Taruma Negara.

Tim Redaksi Gurindam 12.com. (2012). Menongkah Kerang: Tradisi yang Tak Lekang oleh Zaman. Retrieved from http://gurindam12

Wahyuni, D. (2013, June 29). Dilema Duanu. Riau Pos. Pekanbaru. Retrieved from http://www.riaupos.co/2047-opini-dilemaduanu.html

Widiatedja, I. P. (2011). Kebijakan Liberasi Pariwisata: Konstruksi Konsep, Ragam Masalah, dan Alternatif Solusi. Denpasar: Udayana University Press.

Zaini, M. (2014). Cerita Lisan "Yong DOllah": Pewarisan dan Resistensi Budaya Orang Melayu Bengkalis. Madah, 5(1), 1-14. 